\title{
Clare Gerada: Doctors and their defences
}

\author{
Clare Gerada GP partner
}

Hurley Group, London, UK

Working as a doctor is draining-emotionally, intellectually, and physically. Doctors bear the burden of some of the most painful aspects of patients' problems, they witness trauma, and they regularly deal with loss. And no one benefits if doctors break down every time they have to give bad news to a patient. To survive a lifetime in medicine doctors must learn techniques to cope with their job. They need to stay emotionally present without becoming distant. They must prevent overidentification, remain patient centred, and maintain professional boundaries.

Some of these techniques are practical: time management, delegation, safety netting, and "housekeeping." Others involve friends, family, mentors, and peer groups who can provide a buffer for work related stress and improve job satisfaction. ${ }^{2-5}$

But the most useful coping mechanisms are beyond conscious control. These are psychological defence mechanisms.

During a career in medicine doctors learn a set of important defence mechanisms, through modelling and attachment to well functioning groups. ${ }^{6}$ The most commonly used in medicine are denial, ${ }^{7}$ altruism, depersonalisation, and even humour. Humour can alter the content of a potentially disturbing scenario, making it lighter and more tolerable.

Some others are used when in an unfamiliar role-intellectualisation, for example. When unwell, doctors can read and research their own medical condition exhaustively to help distance themselves emotionally from its impact on their life.

Psychological defences, first defined by Sigmund Freud, are strategies brought into play by the unconscious mind to manipulate, deny, or distort reality to defend against feelings of anxiety and unacceptable impulses. Without these defences doctors would be more vulnerable to the effects of exposure to distress, disability, and death and more prone to depression, anxiety, and burnout. They are needed to protect against overidentification with patients and to mask feelings of guilt, fear, and hopelessness.

Without psychological defences doctors would be more vulnerable to the effects of exposure to distress, disability, and death
But these defences can also create problems and work against the individual's wellbeing. Altruism, for example, can become martyrdom, with doctors neglecting their own needs or those of their families. Denial can lead to rejection of vulnerability, with loss of insight and perspective. It can even lead to denial of responsibility in an error or significant event at work, as doctors may instead blame others or outside forces, including the regulator or inspectorate. And emotional distancing, or depersonalisation, can become emotional deadening_leading to burnout, loss of compassion, and even dislike and resentment of patients.

Ensuring a balance between using defence mechanisms to cope with a medical career and their potential to lead to serious personal and professional problems is vital. This can be achieved by making sure that doctors are supported throughout their career. They must also have the space and time to discuss the emotional impact of their work and their own ways of coping in a safe, confidential, and supportive setting.

Competing interests: See www.bmj.com/about-bmj/freelance-contributors.

Provenance and peer review: Commissioned; not externally peer reviewed.

Neighbour R. The inner consultation. MTP, 1987.

2 Thoits PA. Mechanisms linking social ties and support to physical and mental health. $J$ Health Soc Behav 2011;52:145-61. 10.1177/0022146510395592 21673143

3 Lee FJ, Stewart M, Brown JB. Stress, burnout, and strategies for reducing them: what's the situation among Canadian family physicians? Can Fam Physician 2008;54:234-5.18272641

4 Jovanovic A, Wallace JE. Lean on me: an exploratory study of the spousal support received by physicians. Psychol Health Med 2013;18:543-51.

10.1080/13548506.2013.765018 23360286

5 Littlewood S, Case P, Gater R, Lindsey C. Recruitment, retention, satisfaction and stress in child and adolescent psychiatrists. Psychiatr Bull

2003;27:61-710.1192/S0955603600001434.

6 Grohol JM. 15 common defense mechanisms. Psych Central 2017. https://psychcentral. com/lib/15-common-defense-mechanisms/.

7 Leming MR, Dickinson GE. Understanding dying, death and bereavement. 4th ed. Harcourt Brace College Publishers, 1998.

Published by the BMJ Publishing Group Limited. For permission to use (where not already granted under a licence) please go to http://group.bmj.com/group/rights-licensing/ permissions 
